\title{
Perirectal Lymph Node
}

National Cancer Institute

\section{Source}

National Cancer Institute. Perirectal Lymph Node. NCI Thesaurus. Code C154774.

A lymph node that is located in the connective tissue adjacent to the rectum. 